\title{
Tingkatkan Hasil Belajar IPA Siswa Kelas V SD Dengan Media Video Animasi Pembelajaran
}

\author{
Made Dian Supriyani1 ${ }^{*}$, I Gusti Ngurah Japa ${ }^{2}$, I Gede Margunayasa ${ }^{3}$
}

1,2,3 Program Studi Pendidikan Guru Sekolah Dasar, Universitas Pendidikan Ganesha, Singaraja, Indonesia

\section{ART ICLE IN F O}

Article history:

Received March 09, 202

Revised April 15, 2021

Accepted September 30, 2021

Available online October 25, 2021

Kata Kunci:

Video Animasi,Media

Pembelajaran, IPA

Keywords:

Animation Videos, Learning

Media, Science

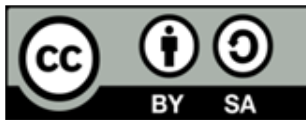

This is an open access article under the CC BY-SA license.

Copyright (C) 2021 by Author. Published by Universitas Pendidikan Ganesha

\begin{abstract}
A B S T R A K
Keterbatasan guru dalam merancang media pembelajaran yang dapat digunakan dalam pembelajaran daring membuat guru tidak menggunakan media pembelajaran dalam melaksanakan pembelajaran daring. Dengan adanya hal tersebut akan membuat siswa tidak termotivasi sehingga hasil belajar siswa akan menurun. Penelitian ini bertujuan untuk menghasilkan video animasi pembelajaran IPA yang teruji validitasnya untuk meningkatkan hasil belajar IPA SD kelas V. Penelitian ini merupakan penelitian pengembangan dengan menggunakan model ADDIE. Subjek dalam penelitian ini adalah 2 orang ahli materi pelajaran IPA, 2 orang ahli media pembelajaran, 2 orang praktisi dan 12 orang respon siswa. Metode pengumpulan data menggunakan instrumen berupa rating scale 5 dengan lembar penilain validitas video animasi pembelajaran IPA untuk meningkatkan hasil belajar IPA SD kelas V. Teknik analisis data menggunakan teknik analisis deskriptif kuantitatif dan kualitatif. Hasil analisis uji validitas yang dilaksanakan diketahui bahwa video animasi pembelajaran IPA untuk meningkatkan hasil belajar IPA SD kelas $V$ yang dikembangkan memperoleh hasil validitas rata-rata sebesar 4,56 dengan kualifikasi "sangat tinggi". Sehingga penelitian ini menghasilkan video animasi pembelajaran IPA untuk meningkatkan hasil belajar IPA SD kelas $V$ yang sudah teruji validitasnya layak. Dengan adanya media pembelajaran video animasi dengan muatan IPA dapat membantu guru dalam menyampaikan materi pembelajaran dan membatu siswa dalam memahami materi pelajaran dalam pembelajaran daring.
\end{abstract}

\section{A B S T RA C T}

The limitations of teachers in designing learning media that can be used in online learning make teachers not use learning media in carrying out online learning. This will make students unmotivated so that student learning outcomes will decrease. This study aims to produce an animated science learning video whose validity has been tested to improve science learning outcomes for fifth grade elementary school students. This research is development research using the ADDIE model. The subjects in this study were 2 science subject matter experts, 2 learning media experts, 2 practitioners and 12 student responses. The data collection method used an instrument in the form of a rating scale 5 with a validity assessment sheet for science learning animation videos to improve science learning outcomes for elementary school grade $V$. The data analysis technique used quantitative and qualitative descriptive analysis techniques. The results of the analysis of the validity test carried out showed that the animated science learning video to improve science learning outcomes for elementary school grade $V$ developed obtained an average validity result of 4.56 with a "very high" qualification. So that this research produces an animated science learning video to improve science learning outcomes for fifth grade elementary school students whose validity has been proven to be feasible. With the existence of animated video learning media with science content, it can help teachers deliver learning materials and help students understand subject matter in online learning.

\section{PENDAHULUAN}

Pandemic covid-19 menyebabkan dunia pendidikan harus dilaksanakan secara terbatas atau berjauhan (Anhusadar, 2020; Muftahu, 2020). Pelaksanaan pendidikan secara berjauhan atau terbatas tersebut dilakukan dengan berbantuan pada teknologi yang telah berkembang dengan sangat pesat (Herwin et al., 2021; Shah et al., 2021). Pembelajaran yang dilaksanakan dengan berbatuan teknologi dan dengan jaringan internet tersebut 
dapat diartikan sebagai pembelajaran daring (Jayul \& Irwanto, 2020; Yanti et al., 2020). Pembelajaran daring sebenarnya telah lama dikenal namun tidak dilakukan secara menyeluruh dengan baik (Kusumawati \& Nayazik, 2018). Akan tetapi, dengan adanya pandemic covid 19 menyebabkan pembelajaran daring menjadi wajib dilaksanakan oleh sekolah- sekolah agar tetap dapat memberikan layanan pendidikan yang sewajarnya kepada siswa (Juanda et al., 2021; Yustina et al., 2020). Pelaksanaan pembelajaran daring dalam situsi pandemic covid19 ditujukan untuk memberikan pengalaman belajar yang sama layaknya pada pembelajaran tatap muka biasanya (Ellianawati et al., 2021; Octaberlina \& Muslimin, 2020). Dengan demikian maka dalam pembelajaran daring guru perlu merancang pembelajaran daring yang sama dengan pembelajaran tatap muka (Hatem Rashid, 2020; Santika, 2020). Maka dari itu dalam pembelajaran daring, guru sangat memerlukan adanya adanya media pembelajaran dalam menyampaikan materi pelajaran (Sakiah \& Effendi, 2021). Adanya media pembelajaran dalam pembelajaran daring akan memudahkan guru dalam menyampaikan materi pelajaran kepada siswa walaupun dengan jarak yang berjauhan (Subandi et al., 2018). Adanya media pelajaran dalam pembelajaran daring juga dapat memrikan kemudahan bagi siswa dalam memahami materi pelajaran yang diberikan oleh gurunya (Mustofa Abi Hamid et al., 2020). Maka dari itu, media pembelajaran sangat penting ada dalam pembelajaran daring (Angela et al., 2021; Fauzy \& Nurfauziah, 2021).

Namun kenyataanya dilapangan masih banyak guru yang tidak menggunakan media pembelajaran dalam pelaksanaan pembelajaran. Dalam pelaksanaan pembelajaran luring maupun daring guru jarang menggunakan media pelajaran yang diakibatkan karena ketersediaan media pembelajaran yang kurang ataupun keterbatasan guru dalam mengembangakan media pembelajaran yang sesuai. Hal tersebut sesuai dengan hasil observasi awal yang telah dilakukan sebelumnya. Pada observasi awal yang telah dilakukan diketahui bahwa permasalahan dalam pembelajaran daring yaitu dalam pembelajaran daring guru jarang menggunakan media pembelajaran. Dalam pembelajaran daring guru hanya mengirimkan materi pelajaran kepada siswa saja dan meminta siswa mengerjakan tugas dari materi yang telah guru berikan. Hal tersebut disebabkan karena keterbasan kemampuan guru dalam mengembangakan media pelajaran yang sesuai dengan materi pelajaran yang diajarkan serta dapat digunakan dalam pembelajaran daring. Dengan tidak menggunakan media pelajaran dalam pelaksanaan pembelajaran daring membuat siswa kesualitan dalam mengikuti pelajaran daring (Fauzy \& Nurfauziah, 2021; Husna et al., 2021). Kesulitan tersebut dikarenakan materi yang guru berikan tidak dijelaskan kepada siswa sehingga menyulitkan siswa dalam memahami materi yang guru berikan (Hebebci et al., 2020; Simamora et al., 2018). Siswa sekolah dasar sangat memerlukan adanya penjelasan dari gurunya mengenai materi yang diberikan sehingga materi lebih mudah dipahami oleh siswa (Oktavia \& Agustin, 2019). Kesulitan dalam memahami materi pelajaran tersebut akan membuat hasil belajar siswa akan menurun sehingga sangat diperlukan adanya pemecahan masalah tersebut sehingga hasil belajar siswa akan meningkat (Aryantini et al., 2021; Nomleni \& Manu, 2018).

Solusi yang dapat dilakukan untuk mengatasi permasalahan tersebut adalah dengan mengembangkan media pelajaran yang dapat memasukkan penjelasan dari guru dan dapat digunakan dalam pembelajaran daring (Rahmatika et al., 2021; Widarti et al., 2020). Media pembelajaran tersebut misalnya media video pembelajaran (Fahrurozi et al., 2017; Khairani \& Qurata Ain, 2021). Media video pembelajaran merupakan salah satu alat bantu audio dan visual secara bersamaan yang dapat menampilkan suatu objek bertujuan untuk menyampaikan sebuah proses, menjelaskan konsep serta mengajarkan keterampilan yang ditargetkan yang dapat mempengaruhi sikap peserta didik (Fiorella \& Mayer, 2018; Nicolaou et al., 2019). Dengan menggunakan media pelajaran video pembelajaran dapat memberikan pengalaman belajar yang langsung diajar oleh gurunya walaupun tidak diajat secara langsung (Alim et al., 2019; Kim, 2020). Penggunaan media pembelajaran video pembelajaran akan membantu guru dalam menyampaikan materi pelajaran secara langsung kepada siswa dalam pembelajaran daring (M. A. Hamid et al., 2020; Syahroni et al., 2020). Selain itu, penggunaan media video pembelajaran dapat memberikan bantuan kepada siswa dalam memahami materi pelajaran kepada siswa dalam pembelajaran daring (Astini, 2020; Rasmitadila et al., 2020).

Beberapa penelitian sebelumnya yang dilakukan untuk mengembangkan video pembelajaran. Penelitian sebelumnya yang telah dilakukan yang telah mengembangakan media video pembelajaran yang menghasilkan bahwa media video pembelajaran dinyatakan efektif digunakan dalam pembelajaran (Nuritha \& Tsurayya, 2021; Wisada et al., 2019). Penelitian laiannya yang telah dilakukan juga yang telah mengembangakan media video pembelajaran dinyatakan layak digunakan dalam pembelajaran karena dapat membantu guru dalam menyampaikan materi pelajaran serta dapat meningkatkan minat belajar siswa dalam proses pembelajaran (Tegeh et al., 2019a; Yuanta, 2020). Penelitian yang telah dilakukan sebelumnya juga menghasilkan bahwa media video animasi yang dikembangkan dapat memberikan pengaruh yang signifikan terhadap perkembangan kognitif siswa (Hanif, 2020; Zakir et al., 2021). Meskipun telah banyak penelitian yang dilakukan untuk mengembangkan media video pembelajaran, namun masih sedikit terdapat penelitian yang dilakukan mengembangakan media video pembelajaran dengan menggunakan konsep animasi. Dengan menggunakan konsep animasi dalam video pembelajaran akan membuat minat siswa menigkat dalam mengikuti pembelajaran daring sehingga akan meningkatkan hasil belajar siswa. Tujuan penelitian ini adalah untuk menghasilkan media pelajaran video animasi dengan muatan pelajaran IPA untuk siswa kelas $\mathrm{V}$ sekolah dasar. Media video pembelajaran dikembangkan dengan muatan pelajaran IPA kelas V sekolah dasar dengan muatan materi 
komponen ekosistem dan jarring-jaring makanan di lingkungan sekitar. Media video pembelajaran dikembangkan dengan menggunakan animasi pada materi dalam video pembelajaran.

\section{METODE}

Jenis penelitian ini adalah penelitian pengembangan. Subjek penelitian ini adalah siswa kelas IV. Rancangan penelitian ini menggunakan Model ADDIE. ADDIE merupakan singkatan dari Analysis, Design, Development or Production, Implementation or Delivery and Evaluations (Ismail, 2018). Model ADDIE ini memiliki 5 Tahapan, yaitu Analyze (menganalisis), Design (merancang), Development (mengembangkan), Implementation (mengimplementasikan), Evaluation (mengevaluasi) (Tegeh \& Kirna, 2010). Pemilihan model ini didasarkan pada model ini dapat digunakan untuk berbagai macam bentuk pengembangan produk seperti model, strategi pembelajaran, metode pembelajaran, media dan bahan ajar. Desain model pengembangan ADDIE yang digunakan dalam pengembangan di tunjukkan pada Gambar 1.

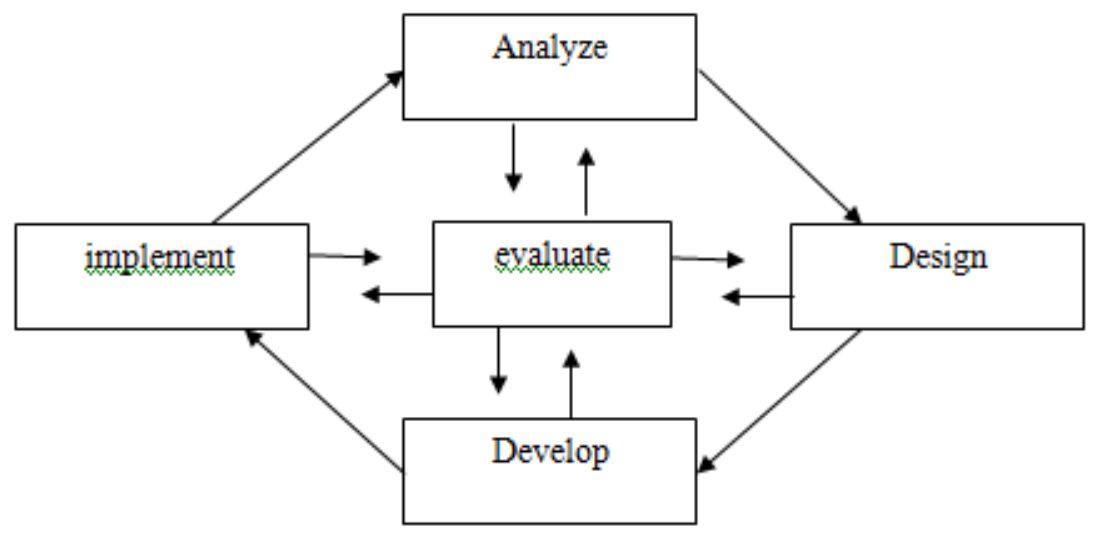

Gambar 1 Desain Model Pengembangan ADDIE

(Ismail, 2018)

Subjek penelitian dalam penelitian pengembangan media video ini yaitu 2 orang ahli materi, 2 orang ahli media, 2 orang guru (praktisi) dan 12 orang siswa. Ahli media dalam penelitian ini yaitu dosen yang berkompeten dibidang media pembelajaran untuk sekolah dasar. Ahli materi dalam penelitian ini yaitu dosen yang berkompeten dibidang muatan pembelajaran IPA jenjang sekolah dasar. Guru sebagai responden dalam penelitian ini merupakan guru yang telah memiliki jenjang pendidikan minimal strata 1 yang mengajar di kelas IV SD. Serta siswa sebagai responden dalam penelitian ini merupakan siswa sekolah dasar yang sedang menempuh pendidikan di kelas IV. Metode pengumpulan data yang akan digunakan peneliti dalam penelitiannya, yaitu observasi, wawancara, dan angket (kuisioner). Kegiatan observasi dilakukan dengan tujuan untuk mengamatinya peneliti akan melakukan pada saat pembelajaran daring. Wawancara dilakukan dengan tujuan untuk memperoleh informasi yang dilakukan dengan tanya jawab terhadap responden dengan menggunakan panduan wawancara. Kuisioner adalah teknik pengumpulan informasi yang di dalamnya berisikan kalimat tanya. Instrument yang digunakan dalam penelitian ini adalah kuisioner yang merupakan suatu alat ukur atau atal pengumpulan data yang digunakan untuk mengumpulkan data dalam suatu penelitian. Adapun kisi-kisi instrument dalam penelitian ini tersaji pada Tabel 1.

Tabel 1 Kisi-Kisi Instrumen Penilaian Produk

\begin{tabular}{|c|c|c|c|}
\hline Ahli/Responden & Aspek & Indikator & Jumlah Butir \\
\hline \multirow[t]{7}{*}{ Ahli Materi Pelajaran } & \multirow[t]{2}{*}{ Pembelajaran } & Tujuan pembelajaran & 3 \\
\hline & & Pemilihan Materi & 3 \\
\hline & \multirow[t]{3}{*}{ Materi } & Kedalaman Materi & 2 \\
\hline & & Hubungan Materi Terhadap & 3 \\
\hline & & Tingkat Perkembangan Siswa & 3 \\
\hline & \multirow[t]{2}{*}{ Isi } & Keruntunan Isi & 2 \\
\hline & & $\begin{array}{l}\text { Kemenarikan Isi } \quad \text { Dalam } \\
\text { Memotivasi Siswa }\end{array}$ & 2 \\
\hline \multirow[t]{4}{*}{ Ahli Media Pelajaran } & \multirow[t]{2}{*}{ Kualitas Media } & Kualitas video yang ditampilkan. & 4 \\
\hline & & Kemudahan penggunaan. & 2 \\
\hline & \multirow[t]{2}{*}{ Desain Media } & $\begin{array}{l}\text { Kesederhanaan media yang } \\
\text { digunakan }\end{array}$ & 3 \\
\hline & & Kejelasan Suara dan Teks & 2 \\
\hline
\end{tabular}




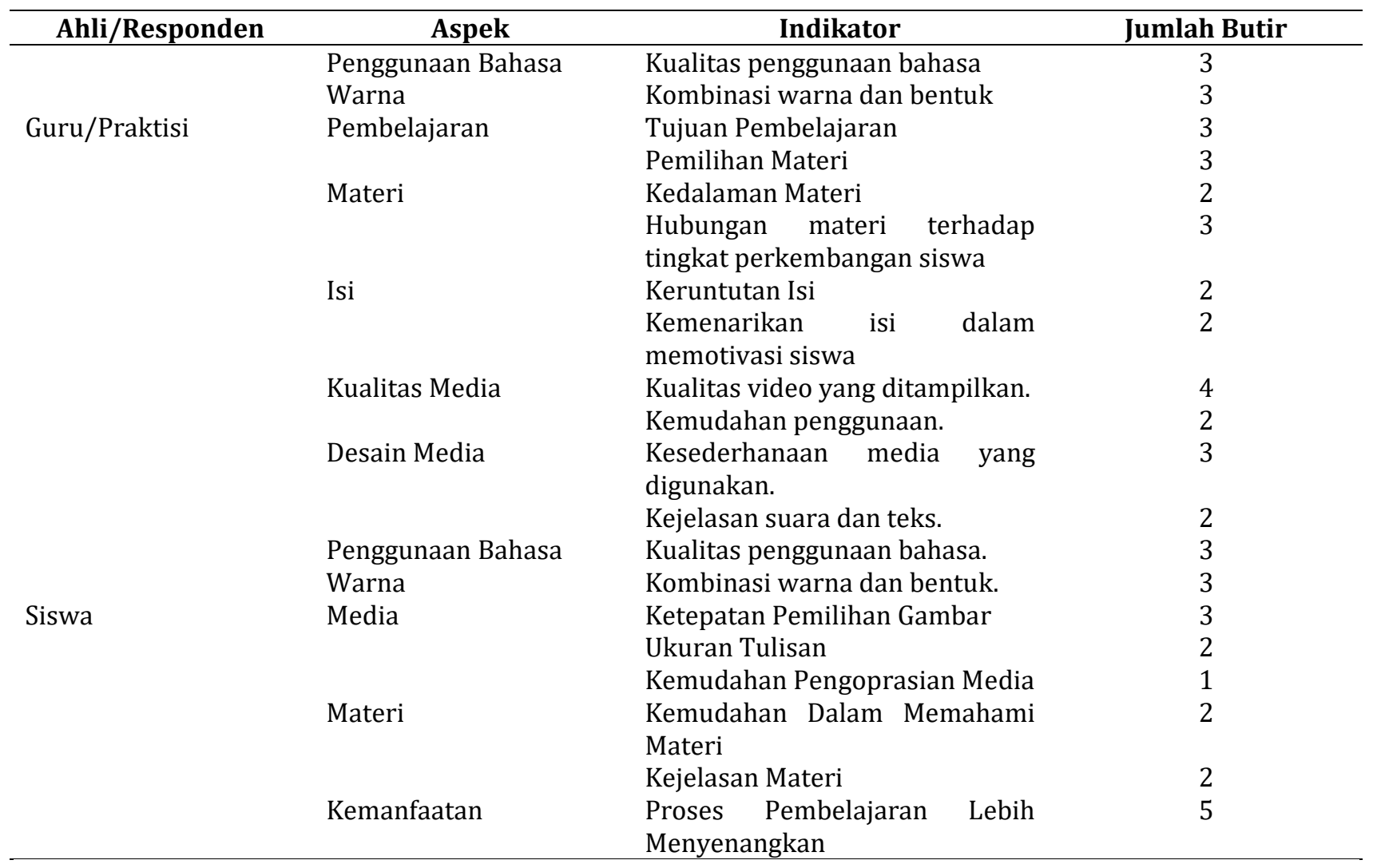

Setelah instrument selesai disusun, instrument kemudian dilakukan uji validitas isi. Validitas isi adalah penjelasan tentang suatu alat ukur secara substantif atau disebut validitas substantif yang fokus kepada konseptualisasi dan sejauhmana konsep-konsep sebelumnya yang ditampilkan dalam kajian literatur. Dalam penelitian ini analisis validitas isi pada penilaian menggunakan menggunakan rumus Gregory dalam mekanisme para pakar yang ditunjuk melakukan penilaian terhadap instrumen dengan mengklasifikasikan butir soal menjadi sangat relevan (skor 3 atau 4) dan kurang relevan (skor 1 atau 2), Hasil penilaian pakar ditabulasi dalam bentuk matriks 2x2. Selanjutnya dibuat tabulasi silang. Setelah mendapatkan hasil analisis content validity kemudian dibandingkan hasil perhitungan yang didapat dengan koefisien validasi isi. Adapun kategori koefisien validitas isi sesuai dengan Tabel 2.

Tabel 2 Koefisien Validitas Isi

\begin{tabular}{cc}
\hline Koefisien & Kriteria \\
\hline $0,80-1,00$ & Validitas isi sangat tinggi \\
$0,60-0,79$ & Validitas isi tinggi \\
$0,40-0,59$ & Validitas isi sedang \\
$0,20-0,39$ & Validitas isi rendah \\
$0,00-0,19$ & Validitas isi sangat rendah \\
\hline
\end{tabular}

(Asmar \& Suryadarma, 2021)

Metode dan teknik analisis data yang digunakan pada penelitian ini yaitu teknik analisis statistik deskriptif kualitatif dan analisis statistik deskripsi kuantitatif. Metode analisis statistik deskriptif kuantitatif merupakan prosedur penelitian yang digunakan untuk mengolah data yang berupa kata-kata tertulis maupun lisan hasil review ahli (Agung, 2014). Teknik analisis data dilakukan dengan mengumpulkan informasi-informasi dari data kualitatif, seperti tanggapan, masukan, kritik, dan saran terhadap media video yang digunakan untuk memperbaiki media video yang dikembangkan. Analisis deskriptif kuantitatif ialah suatu cara pengolahan data yang dilakukan dengan jalan menyusun secara sistematis dalam bentuk angka-angka dan atau presentase, mengenai suatu objek yang diteliti, sehingga diperoleh kesimpulan umum (Agung, 2014). Dalam penelitian ini, analisis dekriptif kuntitatif digunakan untuk mengolah data yang diperoleh melalui angket dalam bentuk skor. Untuk mengetahui validitas suatu produk yang dikembangkan skor diperoleh kemudian dihitung rata-ratannya menggunakan rumus mean. Apabila ata-rata skor sudah diperoleh, untuk dapat memberikan makna dan pengambilan keputusan digunakan ketetapan konversi tingkat pencapaian dengan skala 5 yang disajikan pada Tabel 3. 
Tabel 3 Konversi Tinkat Pencapaian Dengan Skala 5

\begin{tabular}{cc}
\hline Rentangan Skor & Predikat \\
\hline $4,0<\mathrm{X} \leq 5,0$ & Sangat baik \\
$3,3<\mathrm{X} \leq 4,0$ & Baik \\
$2,7<\mathrm{X} \leq 3,3$ & Cukup \\
$2,0<\mathrm{X} \leq 2,7$ & Tidak baik \\
$1,0<\mathrm{X} \leq 2,0$ & Sangat tidak baik \\
\hline
\end{tabular}

(Koyan, 2012).

\section{HASIL DAN PEMBAHASAN}

Hasil

Tahap Analisis merupakan tahapan pertama dalam penelitian ini yang dilakukan melalui 3 tahapan kegiatan yaitu analisis kebutuhan, analisis kurikulum, dan analisis karakteristik siswa. Hasil yang diperoleh pada analisis kebutuhan yaitu diketahui bahwa kurangnya media yang mendukung dalam proses pembelajaran, karena guru cenderung menggunakan pembelajaran konvensional yang mana guru lebih banyak menyampaikan informasi dalam proses belajar mengajar guru lebih banyak memanfaatkan buku LKS dan Buku siswa dan menggunakan media pembelajaran yang sederhana. Apalagi dimasa pandemi seperti saat ini yang mana sekolah menerapkan sistem pembelajaran daring. Dengan begitu dapat menimbulkan daya tarik siswa untuk belajar berkurang. Analisis karakteristik siswa dilakukan untuk mengetahui pengetahuan, keterampilan dan perkembangannya. Analisis ini bertujuan untuk mengetahui tingkat kemampuan siswa yang beragam. Hasil yang diperoleh pada analysis karakteristik siswa yaitu pada siswa kelas IV sekolah dasar berada pada tahap perkembangan oprasional kongkrit. Pada tahap analisis kurikulum dilakukan memahami keluasan materi dan menganalisis KI, KD, Menyusun indikator dan tujuan pembelajaran. Pada KI dan KD disesuaikan dengan buku guru dan buku siswa. Kemudian pada indikator dan tujuan pembelajaran disusun dengan memperhatikan karakteristik siswa di kelas tersebut namun disesuaikan dengan KD. Kompetensi Dasar dan indikator dijabarkan pada Tabel 4.

Tabel 4. Kompetensi Dasar dan Indikator Pencapaian Kompetensi

\begin{tabular}{llll}
\hline No & \multicolumn{2}{c}{ Kompetensi Dasar } & \multicolumn{1}{c}{ Indikator } \\
\hline 1 & $\begin{array}{l}3.5 \quad \text { Menganalisis hubungan antar } \\
\text { komponen ekosistem dan jaring-jaring } \\
\text { makanan di lingkungan sekitar. }\end{array}$ & $\begin{array}{l}\text { 3.5.1 Menganalisis hubungan antar komponen ekosistem } \\
\text { dan jaring-jaring makanan di lingkungan sekitar. }\end{array}$ \\
2. & $\begin{array}{l}\text { 4.5 Membuat karya tentang konsep jaring- } \\
\text { jaring makanan dalam suatu ekosistem. }\end{array}$ & $\begin{array}{l}\text { 4.5.1 Membuat karya tentang konsep jaring-jaring } \\
\text { makanan dalam suatu ekosistem. }\end{array}$ \\
\hline
\end{tabular}

Tahap Perencanaan yang merupakan tahap dimana produk yang dikembangkan yaitu video animasi pembelajaran IPA untuk meningkatkan hasil belajar IPA SD kelas V. Pada tahap ini dilakukan penentuan materi yaitu penggolongan hewan berdasarkan jenis makanannya. Kemudian dilanjutkan penyusunan video pembelajaran dengan menggunakan aplikasi Kinemaster. Selanjutnya dilakukan menyusun instrument penilaian terhadap video pembelajaran yang akan dikembangkan. Instrument yang telah disusun kemudian dilakukan uji validitas isi instrument untuk mengetahui kelayakan dari instrument penilaian yang digunakan. Hasil uji validitas isi instrument tersaji pada Tabel 5 .

Tabel 5. Hasil Validitas Isi Instrumen Penilaian Produk

\begin{tabular}{llll}
\hline No & \multicolumn{1}{c}{ Instrumen } & Koefisien & Kriteria \\
\hline 1 & Instrumen Penilaian Ahli Materi & 1,00 & Validitas isi sangat tinggi \\
2 & Instrumen Penilaian Ahli Media & 1,00 & Validitas isi sangat tinggi \\
3 & Instrumen Penilaian Ahli Praktisi (Guru) & 1,00 & Validitas isi sangat tinggi \\
4 & Instrumen Penilaian Respon Siswa & 1,00 & Validitas isi sangat tinggi \\
\hline
\end{tabular}

Tahap Pengembangan merupakan tahap terakhir pada penelitian ini yang dilakukan untuk mengembangkan video animasi pembelajaran materi penggolongan hewan berdasarkan jenis makanannya. Video animasi pembelajaran yang berisikan judul materi, kompeensi dasar, indikator, tujuan pembelajaran, materi penggolongan hewan berdasarkan jenis makanannya beserta contoh gambar, kesimpulan, latihan soal, dan kredit title. Hasil pengembangan produk pada penelitian ini tersaji pada Gambar 2,3,4 dan 5. Setelah produk selesai dikembangkan, produk kemudian dilkukan pengujian kepada ahli, guru dan siswa untuk mengetahui 
validitas dari produk yang dikembangkan. Adapun hasil validasi produk yang dikembangkan disajikan pada Tabel 7.

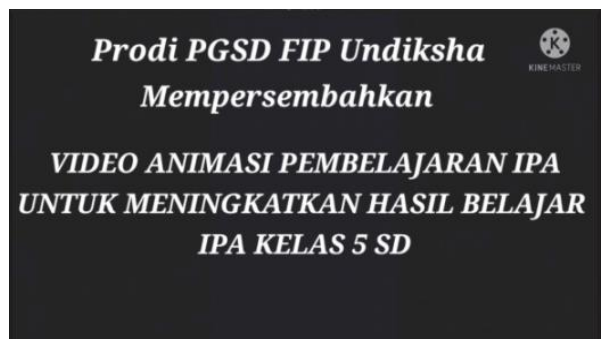

Gambar 2. Tampilan Awal

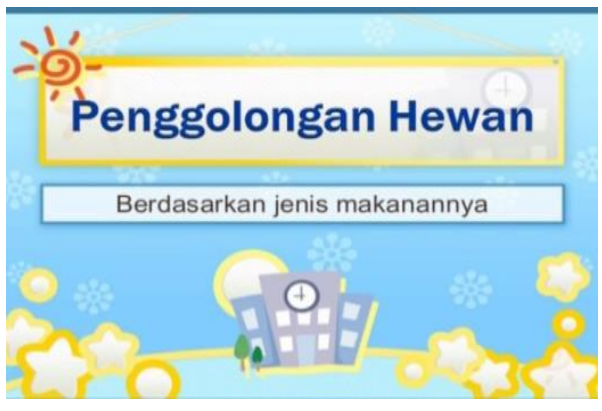

Gambar 3. Tampilan Judul

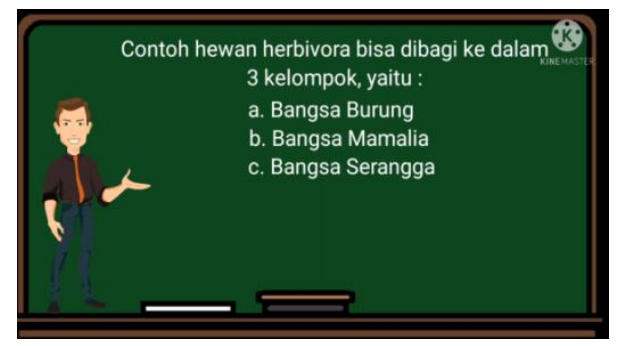

Gambar 4. Tampilan Materi

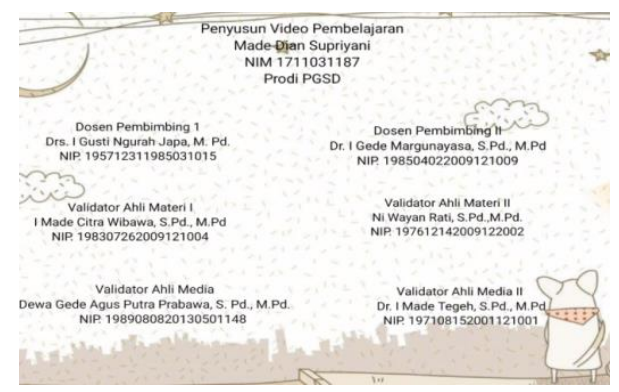

Gambar 5. Tampilan Penutup

Tabel 6 Hasil Uji Validitas Produk

\begin{tabular}{llll}
\hline No & Ahli/Responden & Rata-Rata & Kualifikasi \\
\hline 1 & Ahli Materi Pelajaran & 4,63 & Sangat Baik \\
2 & Ahli Media Pelajaran & 4,30 & Sangat Baik \\
3 & Ahli Praktisi (Guru) & 4,80 & Sangat Baik \\
4 & Respon Siswa & 4,52 & Sangat Baik \\
\hline
\end{tabular}

\section{Pembahasan}

Penelitian pengembangan ini menghasilkan produk berupa media video pembelajaran animasi dengan muatan pelajaran IPA yang dapat digunakan untuk meningkatkan hasil belajar IPA SD kelas V. Produk dikembangkan dengan berpatokan pada model pengembangan ADDIE yang hanya sampai pada tahap pengembangan saja. Pengembangan media video animasi pembelajaran layak digunakan untuk meningkatkan hasil belajar kelas V SD. Hal ini dikarenakan beberapa aspek. Pertama, media video animasi sesuai dengan kebutuhan siswa. Hal ini berdasarkan pada tahap analisis diketahui beberapa permasalahan yaitu dalam proses pembelajaran, guru jarang menggunakan media pembelajaran. Dalam proses pembelajaran, diketahui bahwa guru lebih sering melaksanakan pembelajaran secara konvensional saja tanpa menggunakan media pembelajaran. Hal tersebut akan berdampak pada minat belajar siswa akan berkurang sehingga akan berdampak pada hasil belajar siswa yang berkurang (Wyn et al., 2021; Yuwanita et al., 2020). Permalahan lainnya juga diketahui bahwa dalam pembelajaran daring guru tidak menggunakan media pembelajaran sehingga pembelajaran daring yang guru gunakan hanya memberikan materi atau tugas saja kepada siswa. Hal tersebut berdampak pada minat belajar siswa yang berkurang dikarenakan siswa tidak mendapatkan penjelasan materi dari gurunya (Sababalat et al., 2021; Suryani \& Lestari, 2019). Dengan siswa tidak mendapatkan penjelasan materi dari gurunya akan membuat siswa kesulitan dalam memahami materi yang guru berikan (Arsyad \& Kalu, 2021; Nurfadhillah et al., 2021). Maka dari itu akan berdampak pada hasil belajar siswa yang berkurang (Arsyad \& Kalu, 2021; Nurfadhillah et al., 2021).

Kedua aspek materi, materi yang disajikan pada media video animasi pembelajaran menarik minat belajar siswa, meningkatkan perhatian siswa, dapat memotivasi, dan kejelasan suara. Media pembelajaran dapat menyajikan materi pembelajaran dengan kreatif sehingga meningkatkan minat siswa dalam belajar (Knoop-van Campen et al., 2020; Yuniarni et al., 2020). Selain itu media ini sesuai dengan karakteristik siswa, karakteristik siswa dimana diketahui bahwa siswa sekolah dasar kelas V berada pada tahap oprasional kongkrit. Siswa yang berada pada tahap oprasional kongkrit ini hanya dapat memahami materi yang masih bersifat kongkrit saja (Bujuri, 2018; Septianti \& Afiani, 2020). Dengan hal tersebut maka siswa yang berada pada tahap oprasional kongkrit sangat memerlukan adanya bantuan untuk memahami materi yang bersifat abstrak (Muryaningsih, 2021; Ramadani \& Oktiningrum, 2020). Dari aspek ketepatan, kejelasan pada video pembelajaran memberikan 
dampak bagi siswa. Hal ini sesuai dengan teori yang menyatakan bahwa media pembelajaran adalah segala sesuatu yang digunakan untuk menyalurkan informasi dari pengirim dan penerima sehingga dapat merangsang pikiran, perhatian, dan minat siswa (Asnur \& Ambiyar, 2018; Kurniawan et al., 2017; Maqfiroh et al., 2020; Tegeh et al., 2019b). Beberapa faktor yang mempengaruhi hasil belajar siswa salah satunya berasal dari luar seperti penggunaan alat-alat dalam kegiatan belajar mengajar. Manfaat penggunaan media pembelajaran video dalam pembelajaran adalah memperjelas penyajian materi sehingga proses pembelajaran lebih efektif (Pramana et al., 2016; Yudha et al., 2017). Oleh karena itu, media video animasi pembelajaran layak digunakan pada proses pembelajaran.

Ketiga, media video pembelajaran mendapatkan kualifikasi sangat baik dan layak diterapkan disebabkan karena media yang dikembangkan memudahkan siswa dalam memahami materi pelajaran dengan animasi yang disajikan. Dengan menggunakan animasi yang menarik bagi siswa akan memebrikan kesan yang menarik bagi siswa. Hal tersebut akan membuat minat belajar siswa akan meningkat (Novita et al., 2019; Panjaitan et al., 2020). Selain itu, kelayakan media video pembelajaran animasi dengan muatan pelajaran IPA dapat dilihat pada aspek kesesuaian dengan kegunaan media pelajaran. Media video pembelajaran animasi dengan muatan IPA dirancang menjadi media pembelajaran yangdapat digunakan dalam pembelajaran daring ataupun luring. Dengan dirancang seperti itu akan membuat prosen pembelajaran daring dapat dilaksanakan dengan baik. Penggunaan media dalam pembelajaran daring akan dapat memberikan kemudahan bagi guru dalam menyampaikan materi pelajaran kepada siswa meskipun tidak bertemu langsung dengan siswa (Hanifah Salsabila et al., 2020; Ilmi \& Kurniawan, 2021; Ristiyana et al., 2021; Yamtinah et al., 2021). Selain itu, dengan menggunakan media video pelajaran animasi ini dalam pembelajaran daring akan memudahkan siswa dalam memahami materi dalam pembelajaran daring meskipun tidak dijelaskan secara langsung oleh gurunya (Zakaria et al., 2021). Kelayakan media video pembelajaran animasi dengan muatan pelajaran IPA dapat dilihat juga dari aspek materi yang termuat dalam video pembelajaran. Materi dalam video pembelajaran animasi memuat materi IPA kelas V sekolah dasar yang sesuai dengan kurikulum 2013. Dengan sesuai pada materi yag ada dalam kurikulum 2013 akan membuat media pelajaran video animasi dapat digunakan dalam pembelajaran daring sesuai dengan tujuan pelajaran yang ada pada kurikulum 2013.

Temuan ini diperkuat dengan temuan penelitian sebelumnya menyatakan media video pembelajaran dinyatakan efektif digunakan dalam pembelajaran (Nuritha \& Tsurayya, 2021; Wisada et al., 2019). Media video pembelajaran dinyatakan layak digunakan dalam pembelajaran karena dapat membantu guru dalam menyampaikan materi pelajaran serta dapat meningkatkan minat belajar siswa dalam proses pembelajaran (Tegeh et al., 2019a; Yuanta, 2020). Dengan adanya media video pembelajaran animasi dengan muatan pelajaran IPA dapat memberikan bantuan kepada siswa dalam memahami materi. Siswa yang lebih mudah dalam memahami materi pelajaran akan membuat hasil belajar siswa akan meningkat juga. Selain itu, media video pembelajaran animasi dengan muatan pelajaran IPA didesain atau dirancang dengan menggunakan animasi yang menarik bagi siswa. Impliksi dari adanya penelitian ini yaitu dapat mempermudah guru dalam menyampaikan materi yang diberikan serta dapat membantu mengefisienkan waktu guru untuk menjelaskan materi dalam proses pembelajaran baik luring maupun daring. Selain itu, video animasi pembelajaran dapat menjadi sebagai sarana pembelajaran untuk membantu siswa dalam memahami materi yang diberikan khususnya pelajaran IPA yang mana dalam pelajaran IPA banyak membahas tentang fenoma alam yang mana siswa tidak dapat melihat secara langsung, untuk itu video animasi pembelajaran akan mempengaruhi tingkat pemanahan dan mampu mempengaruhi kecerdasan naturalis pada siswa.

\section{SIMPULAN}

Penelitian pengembangan ini menghasilkan sebuah produk media video animasi pembelajaran dengan muatan pelajaran IPA untuk siswa kelas V sekolah dasar yang dapat digunakan untuk meningkatkan hasil belajar siswa. Produk yang dikembangkan telah dinyatakan valid berdasarkan penilaian oleh para ahli sehingga dapat dinyatakan layak digunakan dalam pembelajaran khususnya pada muatan pelajaran IPA kelas V sekolah dasar. Dengan adanya media pembelajaran video animasi dengan muatan IPA dapat membantu guru dalam menyampaikan materi pembelajaran dan membatu siswa dalam memahami materi pelajaran dalam pembelajaran daring.

\section{DAFTAR PUSTAKA}

Agung, A. A. G. (2014). Metodologi Penelitian Pendidikan. Aditya Media Publishing.

Alim, N., Linda, W., Gunawan, F., \& Saad, M. S. M. (2019). The Effectiveness Of Google Classroom As An Instructional Media: A Case Of State Islamic Institute Of Kendari, Indonesia. Humanities and Social Sciences Reviews, 7(2), 240-246. https://doi.org/10.18510/hssr.2019.7227.

Angela, F., Maimunah, M., \& Roza, Y. (2021). Desain Media Pembelajaran Komik Matematika Berbasis Aplikasi Android pada Materi Persamaan Eksponensial. Jurnal Cendekia: Jurnal Pendidikan Matematika, 5(2), 
1449-1461. https://doi.org/10.31004/cendekia.v5i2.437.

Anhusadar, L. O. (2020). Persepsi Mahasiswa PIAUD terhadap Kuliah Online di Masa Pandemi. KINDERGARTEN: Journal of Islamic Early Childhood Education, 3(1), 44-58. https://doi.org/10.24014/kjiece.v3i1.9609.

Arsyad, N., \& Kalu, D. (2021). Penyebab Miskonsepsi Siswa Kelas 9 pada Materi Pecahan Bentuk Aljabar Berdasarkan Teori Konstruktivisme. 5(2), 143-153. https://doi.org/10.35580/imed23847.

Aryantini, N. K., Sujana, I. W., \& Sri Darmawati, I. G. A. P. (2021). Model Discovery Learning Berbantuan Media Power Point Meningkatkan Hasil Belajar IPA Siswa SD. Jurnal Pedagogi Dan Pembelajaran, 4(2), 251259. https://doi.org/10.23887/jp2.v4i2.36193.

Asmar, A., \& Suryadarma, I. G. P. (2021). Pengembangan Perangkat Pembelajaran IPA Terpadu Model Nested Berbasis Perahu Phinisi untuk Meningkatkan Ket- erampilan Komunikasi dan Pengetahuan Konseptual Pendahuluan. 9(4), 565-578. https://doi.org/10.24815/jpsi.v9i4.20994.

Asnur, L., \& Ambiyar, A. (2018). Penerapan Pembelajaran Menggunakan Media Video Pada Mata Kuliah Tata Boga II. Mimbar Ilmu, 23(3). https://doi.org/10.23887/mi.v23i3.16435.

Astini, S. N. K. (2020). Pemanfaatan Teknologi Informasi dalam Pembelajaran Tingkat Sekolah Dasar pada Masa Pandemi Covid-19. Jurnal Lembaga Penjaminan Mutu STKIP Agama Hindu Amlapura, 11(2), 13-25. https://doi.org/10.47730/jurnallampuhyang.v11i2.194.

Bujuri, D. A. (2018). Analisis Perkembangan Kognitif Anak Usia Dasar dan Implikasinya dalam Kegiatan Belajar Mengajar. LITERASI (Jurnal Ilmu Pendidikan), 9(1), 37. https://doi.org/10.21927/literasi.2018.9(1).3750.

Cahyadi, R. A. H. (2019). Pengembangan Bahan Ajar Berbasis Addie Model. Halaqa: Islamic Education Journal, 3(1), 35. https://doi.org/10.21070/halaqa.v3i1.2124.

Ellianawati, E., Subali, B., Khotimah, S. N., Cholila, M., \& Darmahastuti, H. (2021). Face to Face Mode vs. Online Mode: A Discrepancy in Analogy-Based Learning During COVID-19 Pandemic. Jurnal Pendidikan IPA Indonesia, 10(3), 368-377. https://doi.org/10.15294/jpii.v10i3.30037.

Fadhli, M. (2015). Pengembangan Media Pembelajaran Berbasis Video Kelas IV Sekolah Dasar. Jurnal Dimensi Pendidikan Dan Pembelajaran, 3(1), 24-29. https://doi.org/10.24269/dpp.v3i1.157.

Fahrurozi, S. K., Maryono, D., \& Budiyanto, C. W. (2017). The Development of Video Learning to Deliver a Basic Algorithm Learning. IJIE (Indonesian Journal of Informatics Education), 1(1), 135. https://doi.org/10.20961/ijie.v1i2.12446.

Fauzy, A., \& Nurfauziah, P. (2021). Kesulitan Pembelajaran Daring Matematika Pada Masa Pandemi CoVID-19 di SMP Muslimin Cililin. Jurnal Cendekia: Jurnal Pendidikan Matematika, 5(1), 551-561. https://doi.org/10.31004/cendekia.v5i1.514.

Fiorella, L., \& Mayer, R. E. (2018). What works and doesn't work with instructional video. Computers in Human Behavior, 89, 465-470. https://doi.org/10.1016/j.chb.2018.07.015.

Hamid, M. A., Permata, E., Aribowo, D., Darmawan, I. A., Nurtanto, M., \& Laraswati, S. (2020). Development of cooperative learning based electric circuit kit trainer for basic electrical and electronics practice. Journal of Physics: Conference Series, 1456(1). https://doi.org/10.1088/1742-6596/1456/1/012047.

Hamid, Mustofa Abi, Yuliawati, L., \& Aribowo, D. (2020). Feasibility of electromechanical basic work e-module as a new learning media for vocational students. Journal of Education and Learning (EduLearn), 14(2), 199211. https://doi.org/10.11591/edulearn.v14i2.15923.

Hanif, M. (2020). The development and effectiveness of motion graphic animation videos to improve primary school students' sciences learning outcomes. International Journal of Instruction, 13(4), 247-266. https://doi.org/10.29333/iji.2020.13416a.

Hanifah Salsabila, U., Irna Sari, L., Haibati Lathif, K., Puji Lestari, A., \& Ayuning, A. (2020). Peran Teknologi Dalam Pembelajaran Di Masa Pandemi Covid-19. Al-Mutharahah: Jurnal Penelitian Dan Kajian Sosial Keagamaan, 17(2), 188-198. https://doi.org/10.46781/al-mutharahah.v17i2.138.

Hatem Rashid, A. (2020). Development Of A Holistic Approach Framework For E-Learning Adoption DecisionMaking In Saudi Arabian Universities. Journal of Advances in Technology and Engineering Research, 6(1), 22-36. https://doi.org/10.20474/jater-6.1.3.

Hebebci, M. T., Bertiz, Y., \& Alan, S. (2020). Investigation of Views of Students and Teachers on Distance Education Practices during the Coronavirus (COVID-19) Pandemic. International Journal of Technology in Education and Science, 4(4), 267-282. https://doi.org/10.46328/ijtes.v4i4.113.

Herwin, H., Hastomo, A., Saptono, B., Ardiansyah, A. R., \& Wibowo, S. E. (2021). How Elementary School Teachers Organized Online Learning During The Covid-19 Pandemic? World Journal on Educational Technology: Current Issues, 13(3), 437-449. https://doi.org/10.18844/wjet.v13i3.5952.

Husna, R., Roza, Y., \& Maimunah, M. (2021). Identifikasi Kesulitan Guru Matematika Dalam Pelaksanaan Pembelajaran Daring di Masa Pandemi Covid-19. Jurnal Kependidikan: Jurnal Hasil Penelitian Dan Kajian Kepustakaan Di Bidang Pendidikan, Pengajaran Dan Pembelajaran, 7(2), 428. https://doi.org/10.33394/jk.v7i2.3333.

Ilmi, U., \& Kurniawan, M. A. (2021). Efektivitas Media Audio Visual dalam Pembelajaran PAI Daring di MTs Negeri 9 Yogyakarta. IQRO: Journal of Islamic Education, 4(2), 91-102. 
https://doi.org/10.24256/iqro.v4i2.1997.

Ismail, R. (2018). Perbandingan Keefektifan Pembelajaran Berbasis Proyek Dan Pembelajaran Berbasis Masalah Ditinjau Dari Ketercapaian Tujuan Pembelajaran. Pythagoras: Jurnal Pendidikan Matematika, 13(2), 181188. https://doi.org/10.21831/pg.v13i2.23595.

Jayul, A., \& Irwanto, E. (2020). Model Pembelajaran Daring Sebagai Alternatif Proses Kegiatan Belajar Pendidikan Jasmani di Tengah Pandemi Covid-19. Jurnal Pendidikan Kesehatan Rekreasi, 6(2), 190-199. https://doi.org/10.5281/zenodo.3892262.

Juanda, A., Shidiq, A. S., \& Nasrudin, D. (2021). Teacher Learning Management: Investigating Biology Teachers' Tpack To Conduct Learning During The Covid-19 Outbreak. Jurnal Pendidikan IPA Indonesia, 10(1), 4859. https://doi.org/10.15294/jpii.v10i1.26499.

Khairani, A., \& Qurata Ain, S. (2021). Pengembangan Media Pembelajaran Menggunakan Sparkol Videoscribe Untuk Statistika Siswa Kelas IV SDN 104 Pekanbaru. Qalamuna - Jurnal Pendidikan, Sosial, Dan Agama, 13(2), 219-238. https://doi.org/10.37680/qalamuna.v13i2.898.

Kim, J. (2020). Learning and Teaching Online During Covid-19: Experiences of Student Teachers in an Early Childhood Education Practicum. International Journal of Early Childhood, 52(2), 145-158. https://doi.org/10.1007/s13158-020-00272-6.

Knoop-van Campen, C. A. N., Segers, E., \& Verhoeven, L. (2020). Effects of audio support on multimedia learning processes and outcomes in students with dyslexia. Computers and Education, 150(February), 103858. https://doi.org/10.1016/j.compedu.2020.103858.

Koyan, I. W. (2012). Statistik Pendidikan Teknik Analisis Data Kuantitatif. Universitas Pendidikan Ganesha.

Kurniawan, Agung, \& Tegeh. (2017). Pengembangan Video Pembelajaran Teknik Dasar Sepak Bola Dengan Konsep Quantum Learning. Jurnal Edutech Undiksha, 5(2), 179-188. https://doi.org/10.23887/jeu.v5i2.20374.

Kusumawati, R., \& Nayazik, A. (2018). Developing Mathematics Learning Strategy Module Based on Journal Review. Al-Jabar: Jurnal Pendidikan Matematika, 9(2), 111-120. https://doi.org/10.24042/ajpm.v9i2.3110.

Maqfiroh, Khutobah, \& Budyawati. (2020). Pengembangan Media MOTIF (Monopoli Edukatif) dalam Pembelajaran berbasis Multiple intelligence. Cakrawala Dini: Jurnal Pendidikan Anak Usia Dini, 11(1), 64-74.

Muftahu, M. (2020). Higher Education and Covid-19 Pandemic: Matters Arising and the Challenges of Sustaining Academic Programs in Developing African Universities. International Journal of Educational Research Review, 5(4), 417-423. https://doi.org/10.24331/ijere.776470.

Muryaningsih, S. (2021). Media Pembelajaran Berbahan Loose Part Dalam Pembelajaran Eksak Di Mi Kedungwuluh Lor. Khazanah Pendidikan, 15(1), 84. https://doi.org/10.30595/jkp.v15i1.10360.

Nicolaou, C., Matsiola, M., \& Kalliris, G. (2019). Technology-Enhanced Learning And Teaching Methodologies Through Audiovisual Media. Education Sciences, 9(3), 1-13. https://doi.org/10.3390/educsci9030196.

Nomleni, F. T., \& Manu, T. S. N. (2018). Pengembangan Media Audio Visual dan Alat Peraga dalam Meningkatkan Pemahaman Konsep dan Pemecahan Masalah. Scholaria: Jurnal Pendidikan Dan Kebudayaan, 8(3), 219230. https://doi.org/10.24246/j.js.2018.v8.i3.p219-230.

Novita, L., Sukmanasa, E., \& Pratama, M. Y. (2019). Penggunaan Media Pembelajaran Video terhadap Hasil Belajar Siswa SD. Indonesian Journal of Primary Education Penggunaan, 3(2), 64-72. https://ejournal.upi.edu/index.php/IJPE/article/view/22103.

Nurfadhillah, S., Tantular, L. D., Syafitri, H. A., Fauzan, M. I., \& Haq, A. S. (2021). Analisis Pengembangan Media Interaktif Berbasis Power Point Pada Pembelajaran Jarak Jauh di MI Darussaman. PENSA: Jurnal Pendidikan Dan Ilmu Sosial, 3(2), 267-279. https://doi.org/10.36088/pensa.v3i2.1351.

Nuritha, C., \& Tsurayya, A. (2021). Pengembangan Video Pembelajaran Berbantuan Geogebra untuk Meningkatkan Kemandirian Belajar Siswa. Jurnal Cendekia : Jurnal Pendidikan Matematika, 5(1), 48-64. https://doi.org/10.31004/cendekia.v5i1.430.

Octaberlina, L. R., \& Muslimin, A. I. (2020). Efl Students Perspective Towards Online Learning Barriers And Alternatives Using Moodle/Google Classroom During Covid-19 Pandemic. International Journal of Higher Education, 9(6), 1-9. https://doi.org/10.5430/ijhe.v9n6p1.

Oktavia, A., \& Agustin, H. (2019). Umbul Card: A Traditional Game as Nutrition Education Media among Elementary School Students. International Journal of Educational Research Review, 5(1), 1-9. https://doi.org/10.24331/ijere.646821.

Panjaitan, N. Q., Yetti, E., \& Nurani, Y. (2020). Pengaruh Media Pembelajaran Digital Animasi dan Kepercayaan Diri terhadap Hasil Belajar Pendidikan Agama Islam Anak. Jurnal Obsesi : Jurnal Pendidikan Anak Usia Dini, 4(2), 588. https://doi.org/10.31004/obsesi.v4i2.404.

Pramana, I. P. A., Tegeh, I. M., \& Agung, A. A. G. (2016). Pengembangan Video Pembelajaran IPA Kelas VI di SD N 2 Banjar Bali Tahun 2015/2016. Edutech Undiksha, 5(2). https://doi.org/10.23887/jeu.v4i2.7631.

Rahmatika, Yusuf, M., \& Agung, L. (2021). The Effectiveness of Youtube as an Online Learning Media. Journal of 
Education Technology, 3(1), 152-158. https://doi.org/10.23887/jet.v5i1.33628.

Ramadani, Z., \& Oktiningrum, W. (2020). Pengembangan Media Pembelajaran Matematika "Minitim Kabar" Untuk Meningkatkan Hasil Belajar Kognitif Siswa. Alifmatika: Jurnal Pendidikan Dan Pembelajaran Matematika, 2(2), 152-168. https://doi.org/10.35316/alifmatika.2020.v2i2.152-168.

Rasmitadila, Aliyyah, R. R., Rachmadtullah, R., Samsudin, A., Syaodih, E., Nurtanto, M., \& Tambunan, A. R. S. (2020). The perceptions of primary school teachers of online learning during the covid-19 pandemic period: A case study in Indonesia. Journal of Ethnic and Cultural Studies, 7(2), 90-109. https://doi.org/10.29333/ejecs/388.

Ristiyana, A., Sari, P., \& Suyanta, S. (2021). Measurement in Educational Research critical thinking skills dan science process skills. 1(1), 26-38. https://doi.org/10.33292/meter.v1i1.108.

Sababalat, D. F., Purba, L. S. L., \& Sormin, E. (2021). Efektivitas Pemanfaatan Media Pembelajaran Teka- Teki Silang Online Terhadap Peningkatan Minat Belajar Siswa. EduMatSains, 6(1), 207-218. https://doi.org/10.33541/edumatsains.v6i1.2959.

Sakiah, N. A., \& Effendi, K. N. S. (2021). Analisis Kebutuhan Multimedia Interaktif Berbasis PowerPoint Materi Aljabar Pada Pembelajaran Matematika SMP. JP3M (Jurnal Penelitian Pendidikan Dan Pengajaran Matematika), 7(1), 39-48. https://doi.org/10.37058/jp3m.v7i1.2623.

Santika, I. W. E. (2020). Pendidikan Karakter pada Pembelajaran Daring. Indonesian Values and Character Education Journal, 3(1), 8-19. https://doi.org/10.23887/ivcej.v3i1.27830.

Septianti, N., \& Afiani, R. (2020). Pentingnya Memahami Karakteristik Siswa Sekolah Dasar di SDN Cikokol 2. AsSabiqun, 2(1), 7-17. https://doi.org/10.36088/assabiqun.v2i1.611.

Shah, D., Patel, D., Adesara, J., Hingu, P., \& Shah, M. (2021). Integrating Machine Learning and Blockchain to Develop a System to Veto the Forgeries and Provide Efficient Results in Education Sector. Visual Computing for Industry, Biomedicine, and Art, 4(1), 1-13. https://doi.org/10.1186/s42492-021-00084-y.

Simamora, R. E., Saragih, S., \& Hasratuddin, H. (2018). Improving Students' Mathematical Problem-Solving Ability and Self-Efficacy through Guided Discovery Learning in Local Culture Context. International Electronic Journal of Mathematics Education, 14(1), 61-72. https://doi.org/10.12973/iejme/3966.

Subandi, S., Choirudin, C., Mahmudi, M., Nizaruddin, N., \& Hermanita, H. (2018). Building Interactive Communication With Google Classroom. International Journal of Engineering and Technology(UAE), 7(2.13 Special Issue 13), 460-463. https://doi.org/10.14419/ijet.v7i2.29.13799.

Suryani, D. R., \& Lestari, N. (2019). Penggunaan Variasi Media Pembelajaran Untuk Meningkatkan Motivasi Dan Minat Belajar Matematika Siswa Kelas Xi Ips 3 Sma Negeri 2 Merauke. Musamus Journal of Mathematics Education, 1(2), 74-79. https://doi.org/10.35724/mjme.v1i2.1376.

Syahroni, M., Dianastiti, F. E., \& Firmadani, F. (2020). Pelatihan Media Pembelajaran Berbasis Teknologi Informasi untuk Meningkatkan Keterampilan Guru dalam Pembelajaran Jarak Jauh. International Journal Of Community Service Learning, 4(3), 171-172. https://doi.org/10.23887/ijcsl.v4i3.28847.

Tegeh, I. M., \& Kirna, I. M. (2010). Metode Penelitian Pengembangan Pendidikan. Universitas Pendidikan Ganesha.

Tegeh, I. M., Simamora, A. H., \& Dwipayana, K. (2019a). Pengembangan Media Video Pembelajaran Dengan Model Pengembangan 4D Pada Mata Pelajaran Agama Hindu. Mimbar Ilmu, 24(2), 158. https://doi.org/10.23887/mi.v24i2.21262.

Tegeh, Simamora, \& Dwipayana. (2019b). Pengembangan Media Video Pembelajaran Dengan Model Pengembangan 4D Pada Mata Pelajaran Agama Hindu. Jurnal Mimbar Ilmu, 24(2), 158-166. https://doi.org/10.23887/mi.v24i2.21262.

Widarti, H. R., Rokhim, D. A., \& Syafruddin, A. B. (2020). The Development Of Electrolysis Cell Teaching Material Based On Stem-Pjbl Approach Assisted By Learning Video: A Need Analysis. Jurnal Pendidikan IPA Indonesia, 9(3), 309-318. https://doi.org/10.15294/jpii.v9i3.25199.

Wisada, P. D., Sudarma, I. K., \& Yuda S, A. I. W. I. (2019). Pengembangan Media Video Pembelajaran Berorientasi $\begin{array}{lllll}\text { Pendidikan Karakter. Journal of Education Technology, } & 140 .\end{array}$ https://doi.org/10.23887/jet.v3i3.21735.

Wyn, N., Asriningsih, N., Sujana, I. W., Ayu, I. G., \& Sri, P. (2021). Pengaruh Model Pembelajaran PBL terhadap Hasil Belajar Senam Lantai Ditinjau dari Minat Belajar Peserta Didik. 26(2), 260-267. https://doi.org/10.23887/mi.v26i2.35626.

Yamtinah, Marhaeni, A. A. I. N., \& Lasmawan, I. W. (2021). Pengembangan Instrumen Keterampilan Menulis Karangan dan Kemampuan Berpikir Kreatif Pada Materi Karangan Narasi Siswa Kelas IV Sekolah Dasar. PENDASI: Jurnal Pendidikan Dasar Indonesia, 5(1), 94-104. https://doi.org/10.23887/jurnal_pendas.v5i1.262.

Yanti, M. T., Kuntarto, E., \& Kurniawan, A. R. (2020). Pemanfaatan Portal Rumah Belajar Kemendikbud Sebagai Model Pembelajaran Daring Di Sekolah Dasar. Adi Widya: Jurnal Pendidikan Dasar, 10(1), 61-68. https://doi.org/10.25078/aw.v5i1.1306.

Yuanta, F. (2020). Pengembangan Media Video Pembelajaran Ilmu Pengetahuan Sosial pada Siswa Sekolah Dasar. Trapsila: Jurnal Pendidikan Dasar, 1(02), 91. https://doi.org/10.30742/tpd.v1i02.816.

Yudha, Pudjawan, \& Tegeh. (2017). Pengembangan Video Matembang Sekar Alit Berbasis Model Direct 
Instruction DI SMP Negeri 5 SINGARAJA. Jurnal Edutech Undiksha, 5(1), 19-27. https://doi.org/10.23887/jeu.v5i1.20198.

Yuniarni, Sari, \& Atiq. (2020). Pengembangan Multimedia Interaktif Video Senam Animasi Berbasis Budaya Khas Kalimantan Barat. Jurnal Obsesi : Jurnal Pendidikan Anak Usia Dini, 4(1). https://doi.org/10.31004/obsesi.v4i1.331.

Yustina, Syafii, W., \& Vebrianto, R. (2020). The Effects Of Blended Learning And Project-Based Learning On PreService Biology Teachers' Creative Thinking Skills Through Online Learning In The COVID-19 Pandemic. Jurnal Pendidikan IPA Indonesia, 9(3), 408-420. https://doi.org/10.15294/jpii.v9i3.24706.

Yuwanita, I., Dewi, H. I., \& Wicaksono, D. (2020). Pengaruh Metode Pembelajaran Dan Gaya Belajar Terhadap Hasil Belajar IPA. Instruksional, 1(2), 152. https://doi.org/10.24853/instruksional.1.2.152-158.

Zakaria, P., Nurwan, N., \& Silalahi, F. D. (2021). Deskripsi Kemampuan Berpikir Kritis Siswa Melalui Pembelajaran Daring Pada Materi Segi Empat. Euler: Jurnal Ilmiah Matematika, Sains Dan Teknologi, 9(1), 32-39. https://doi.org/10.34312/euler.v9i1.10539.

Zakir, S., Maiyana, E., Nur Khomarudin, A., Novita, R., \& Deurama, M. (2021). Development of 3D Animation Based Hydrocarbon Learning Media. Journal of Physics: Conference Series, 1779(1). https://doi.org/10.1088/1742-6596/1779/1/012008. 